\title{
Kajian Hukum Perbandingan Kemudahan Investasi Asing di Singapura dan di Kota Batam, Indonesia Beserta Legal Standing OSS Dalam Penerapannya
}

\author{
Abdurrakhman Alhakim, Jessica Sim, Hari Sutra Disemadi \\ Fakultas Hukum,Universitas Internasional Batam, Indonesia \\ Correspondence email: alhakim@uib.ac.id; 1851080.jessica@uib.edu; hari@uib.ac.id
}

\begin{abstract}
Abstrak. Investasi merupakan salah satu langkah awal dalam menggerakkan roda perekonomian suatu negara. Di Kota Batam sendiri sangatlah kental diidentikkan dengan iklim berinvestasi. Dengan lokasinya yang strategis, Kota Batam terletak bersebelahan dengan negara tetangganya yaitu Singapura dan Malaysia. Sistem OSS (Online Single Submission) muncul sebagai salah satu langkah yang bertujuan untuk meningkatkan daya saing kawasan global serta mendorong pertumbuhan investasi. Namun dalam sistem OSS masih banyak ditemukan kendala baik dari segi regulasi maupun pelaksana regulasi yang dinilai masih kurang optimal dalam menerapkan izin usaha yang terintegrasi secara elektronik. Hal tersebut juga diperparah dengan dualisme kewenangan dalam mengelola wilayah. Melirik ke negara tetangga, Negara Singapura merupakan tujuan favorit bagi perusahaan global yang ingin mengembangkan bisnisnya di Asia. Kemudahan memperoleh izin usaha sudah menjadi fokus utama bagi Negeri Singa ini. Penelitian ini menggunakan metode penelitian hukum normatif dengan pendekatan perbandingan hukum dan pendekatan peraturan perundang-undangan. Adapun tujuan dari penulisan artikel ini adalah, untuk mempelajari kemudahan investasi asing di Singapura dibandingkan dengan Kota Batam beserta kedudukan hukum OSS dalam penerapannya. Berdasarkan penelitian yang dilakukan, kemudahan investasi diteliti dari berbagai faktor yaitu di bidang kepastian hukum, perpajakan, ketenagakerjaan, dan perizinan sistem OSS Indonesia termasuk Kota Batam masih belum sepenuhnya mendukung iklim investasi yang kondusif dalam berusaha dibandingkan dengan negara Singapura.
\end{abstract}

Kata kunci : Kemudahan, Investasi, Sistem OSS

\begin{abstract}
Investment is one of the first steps in moving the wheels of a country's economy. In the city of Batam itself is strongly identified with the investment climate. With its strategic location, Batam City is located adjacent to its neighboring countries, namely Singapore and Malaysia. The OSS (Online Single Submission) system emerged as one of the steps aimed at increasing the competitiveness of the global region and encouraging investment growth. However, in the OSS system there are still many obstacles both in terms of regulations and implementers of regulations that are considered less than optimal in applying electronically integrated business licenses. This is also worsen by the dualism of authority in managing the region. Looking to neighboring countries, Singapore is a favorite destination for global companies wishing to expand their business in Asia. The ease of obtaining a business license has become the main focus for this Lion Country. This study uses a normative legal research method with a comparative law approach and a statutory regulation approach. The purpose of writing this article is to study the ease of foreign investment in Singapore compared to Batam City and the legal standing of OSS in its application. Based on the research conducted, the ease of investment is examined from various factors, namely in the areas of legal certainty, taxation, employment, and licensing of the Indonesian OSS system including Batam City which still does not fully support a conducive investment climate in doing business compared to Singapore.
\end{abstract}

Keywords : Ease, Invesment, OSS System

\section{PENDAHULUAN}

Bagi suatu negara investasi merupakan salah satu langkah awal dalam menggerakkan roda perekonomiannya. Dengan adanya investasi, kegiatan produksi dapat dilakukan secara masif dan terarah dalam rangka memajukan tingkat perkembangan ekonomi nasional. ${ }^{1}$ Pada dasarnya investasi juga merupakan salah satu upaya untuk membangun ekonomi negara secara berkelanjutan dan menyeluruh. Tingkat perkembangan ekonomi sangat dipengaruhi oleh dinamika penanaman modal serta dapat mempercepat laju pembangunan. ${ }^{2}$ Persepsi mengenai perannya investasi dalam mendukung pembangunan negara berkembang berawal ketika Perang Dunia II yang terjadi dalam rentang waktu 1950 an hingga 1960 an. Maka, segala upaya membutuhkan likuiditas simpanan eksternal dan internal negara diperlukan agar tercipta investasi yang memadai untuk melajukan tingkat perkembangan ekonomi. ${ }^{3}$

1 Kartikasari, D. (2017). The Effect of Export, Import and Investment to Economic Growth of Riau Island Indonesia. International Journal of Economics and Financial Issues, 7(4), 663-667.

${ }^{2}$ Sari, M., Syechalad, M. N., \& Majid, S. A. (2016). Pengaruh investasi, tenaga kerja dan pengeluaran pemerintah terhadap pertumbuhan ekonomi di Indonesia. Jurnal Ekonomi Dan Kebijakan Publik Indonesia, 3(2), 109-115.

3 Julianti, L., \& Subekti, R. P. (2018). Standar Perlindungan Hukum Kegiatan Investasi Pada Bisnis Jasa Pariwisata Di Indonesia. Kertha Wicaksana, 12(2), 156-166. 
Abdurrakhman Alhakim et al., Kajian Hukum Perbandingan Kemudahan Investasi Asing di Singapura dan di Kota Batam, Indonesia Beserta Legal Standing OSS Dalam Penerapannya

Disamping itu, penanaman modal juga memiliki peranan penting dalam pertumbuhan ekonomi serta pertumbuhan sosial suatu negara. Dengan munculnya investasi modal asing, maka para investor akan mendirikan perusahaan-perusahaan asing dan membuka lapangan pekerjaan dalam jumlah banyak demi memenuhi kebutuhannya akan tenaga kerja agar perusahaan dapat beroperasional dengan lancar. ${ }^{4}$ Terbukanya lapangan kerja akan mengurangi tanggungan pemerintah dalam mengatasi pengangguran serta menurunkan tingkat kriminalitas di suatu wilayah. Dengan adanya penghasilan yang tetap, kemampuan dan kapasitas masyarakat dalam membeli barang maupun jasa akan meningkat dari waktu ke waktu dan menghasilkan dampak positif terhadap pertumbuhan ekonomi suatu negara. ${ }^{5}$

Pembangunan perusahaan-perusahaan asing di negara berkembang juga akan mendorong penyediaan infrastruktur yang lebih baik. Mulai dari fasilitas umum seperti jalan raya, jembatan, pelabuhan, bandara, hingga utilitas umum seperti sumber air bersih, jaringan telekomunikasi, fasilitas pasokan listrik, dan suplai energi. ${ }^{6}$ Selain fasilitas, investasi asing juga membuka peluang bagi pengalihan ilmu pengetahuan dan teknologi transfer dalam rangka peningkatan sumber daya manusia yang inovatif dan berkualitas. Layaknya roda berputar, keuntungan tersebut akan menciptakan iklim ekonomi yang sehat dalam berkompetitif. Dalam iklim ekonomi yang sehat maka terbukalah peluang kerja sama internasional antar negara sehingga Indonesia dapat mencapai cita-citanya dengan mensejahterakan dan memakmurkan rakyatnya di bidang perekonomian. ${ }^{7}$

Di Kota Batam sendiri sangatlah kental diidentikkan dengan iklim berinvestasi. Didukung dengan lokasinya yang strategis, Kota Batam terletak bersebelahan dan diapit oleh dua negara tetangganya yaitu negara Singapura dan negara Malaysia. Hal ini membuat Kota Batam ada di dalam jalur pelayaran internasional. Tak heran, para investor tidak segan-segan mengucurkan dananya di kota ini untuk mendirikan perusahaan-perusahaan asing yang bergerak di berbagai macam sektor. Sektor-sektor yang diminati antara lain jasa konstruksi, industri galangan kapal, komoditi ekspor, sektor perindustrian dan alih kapal, sektor dagang dan jasa yang sekaligus menjadi nadi keekonomian di Kota Batam. $^{8}$

Sistem OSS (Online Single Submission) diciptakan oleh pemerintah sebagai salah satu langkah yang bertujuan untuk meningkatkan daya saing kawasan global serta mendorong pertumbuhan investasi di Indonesia termasuk Kota Batam. Namun sangat disayangkan, dalam pengimplementasian sistem OSS ini masih banyak ditemukan kendala baik dari segi regulasi maupun pelaksana regulasi yang dinilai oleh berbagai kalangan masih kurang optimal dalam menerapkan izin usaha yang terintegrasi secara elektronik. ${ }^{9}$ Hal tersebut juga diperparah dengan dualisme kewenangan dalam mengelola wilayah telah menyebabkan Batam kehilangan daya saing yang berujung pada lambannya perizinan, tumpang tindih pengurusan lahan, ketidakpastian hukum bagi penanam modal, dan penyediaan infrastruktur yang tidak mencapai standar internasional. ${ }^{10}$ Dalam melakukan penanaman modal, investor membutuhkan kepastian hukum serta perlindungan dalam berusaha. Jika suatu negara tidak mampu menyediakan hal tersebut, maka investor enggan dan akan mencari alternatif lain untuk menanamkan modalnya. Sehingga pada realitanya, iklim berinvestasi di Kota Batam kini kian melesu dalam pembangunan serta perkembangan ekonominya. Hal ini ditandai, terutama pada saat gelombang pandemi melanda banyak perusahaan asing yang tidak mampu bertahan dan terpaksa menggulung tikar untuk kembali ke negara asalnya. Alhasil, banyak tenaga kerja harus di lakukan pemutusan hubungan kerja (PHK) dan mengalami pengangguran di saat kondisi ekonomi yang sulit ini. ${ }^{11}$

Melirik ke negara tetangga, Negara Singapura merupakan tujuan favorit bagi perusahaan-perusahaan global yang ingin mengembangkan bisnisnya di Asia. Kemudahan memperoleh izin usaha sudah menjadi fokus utama bagi Negeri Singa ini. Pemerintah Singapura memahami kedudukan negaranya yang memiliki lokasi geografis dan strategis di kawasan Asia serta dapat dengan mudah menjangkau negara tetangganya. Oleh karenanya, mereka sangat mengakomodasi bagi industri maupun perusahaan asing yang berkeinginan memasuki kawasan pasar di Asia ini melalui regulasi yang bersahabat dan lingkungan bisnis yang mendukung. Selain memiliki keuntungan lokasi yang

${ }^{4}$ Ningsih, D., \& Sari, S. I. (2018). Pengaruh Investasi dan Tenaga Kerja Terhadap Pertumbuhan Ekonomi di Kota Batam. Jurnal Akuntansi Barelang, 3(1), 21-31.

${ }^{5}$ Bplawyers, B. (2017). Perkembangan Serta Manfaat Investasi Asing di Indonesia. https://bplawyers.co.id/. Diakses pada tanggal 25 Januari 2021.

${ }^{6}$ Arliman, L. (2018). Peran Investasi dalam Kebijakan Pembangunan Ekonomi Bidang Pariwisata di Provinsi Sumatera Barat. Kanun Jurnal Ilmu Hukum, 20(2), 273-294.

${ }^{7}$ Rahmah, N. (2019). Pengertian, Jenis dan Masalah Infrastruktur serta Solusinya. https://www.pengadaanbarang.co.id/. Diakses pada tanggal 25 Januari 2021.

${ }^{8}$ Itaeba, I. (2019). Tentang Batam. https://iteba.ac.id/. Diakses pada tanggal 26 Januari 2021.

${ }^{9}$ Safei, M. (2019). Permasalahan Kebijakan Pelayanan Terpadu Satu Pintu (PTSP) dan Solusinya. https://osf.io. Diakses pada tanggal 26 Januari 2021.

10 Rivani, E. (2016). Transformasi Batam menjadi KEK untuk memperbaiki iklim investasi. Info Singkat Ekonomi Dan Kebijakan Publik, VIII, 6.

${ }^{11}$ Lumbantobing, B. (2020). Hingga Akhir April, 766 Karyawan di Batam Kena PHK, 325 Perusahaan Terdampak Covid19. https://batam.tribunnews.com/. Diakses pada tanggal 27 Januari 2021. 
strategis, pemerintah Singapura juga memiliki kelebihan lainnya yang tak kalah penting yaitu regulasi yang dikeluarkan pemerintah ramah terhadap usaha untuk menciptakan iklim bisnis yang kondusif. ${ }^{12}$

Negara ini dijuluki dengan nama 'The Four Asians Tiger' (empat negara "Macan Asia”) yakni Singapura, Taiwan, Hongkong, dan Korea Selatan yang memimpin dengan pertumbuhan ekonominya yang pesat. ${ }^{13}$ Meskipun negara Singapura memiliki wilayah yang tidak terlalu luas, Singapura memimpin dunia di antara ke-10 daerah kebebasan ekonomi. Saat ini, tercatat 26.000 industri asing yang menjalankan kegiatan usahanya di Singapura. ${ }^{14}$ Hal tersebut seharusnya memacu Indonesia untuk meningkatkan kualitas regulasinya lebih lagi, khususnya di Kota Batam. Yang mana kita ketahui, Kota Batam dan Negara Singapura letaknya bersebelahan. Kedua wilayah ini sama-sama memiliki keunggulan geografis yang terletak di jalur perdagangan internasional. Namun, jika dibandingkan keduanya memiliki iklim investasi yang jauh berbeda terutama dalam bidang regulasi. ${ }^{15}$

Berdasarkan uraian yang dikemukakan diatas, terdapat isu hukum yang diangkat dalam penelitian ini yang pertama, bagaimana faktor-faktor yang mempengaruhi kemudahan investasi asing di Kota Batam beserta legal standing OSS dalam penerapannya, yang kedua, bagaimana faktor-faktor yang mempengaruhi kemudahan investasi asing di Singapura dan yang ketiga, bagaimana perbandingan kemudahan investasi asing antara Kota Batam dan Singapura. Adapun tujuan dari penulisan artikel ini adalah, untuk mempelajari kemudahan investasi asing di Singapura dibandingkan dengan Kota Batam beserta kedudukan hukum OSS dalam penerapannya. Dengan adanya penelitian ini, diharapkan Kota Batam dapat memetik ilmu untuk meningkatkan iklim investasinya agar semenarik Singapura dalam kemudahan berusahanya serta memiliki pesona bisnis untuk dilirik oleh calon investor negara asing yang ingin menanamkan modalnya.

\section{METODE}

Metode penelitian yang digunakan dalam jurnal ini menggunakan yuridis normatif. Yuridis normatif merupakan jenis penelitian hukum yang diteliti lewat studi kepustakaan, yaitu meneliti bahan-bahan sekunder seperti peraturan perundangan, arsip hukum, hasil penelitian, artikel, serta data hukum lain terkait permasalahan yang ditemukan. Untuk menyelesaikan permasalahan penelitian setidaknya membutuhkan suatu jenis pendekatan. Berdasarkan buku Peter M. dengan judul "Penelitian Hukum" tercatat berbagai jenis pendekatan untuk menganalisa persoalan hukum yang timbul, antara lain. ${ }^{16}$

Pendekatan yang digunakan dalam penelitian ini yakni pendekatan komparatif dan pendekatan perundangundangan. Pendekatan komparatif yaitu membandingkan secara substantif antara kemudahan berinvestasi di Kota Batam dengan kemudahan berinvestasi di Negara Singapura sebagai pembanding. Sedangkan, pendekatan perundangundangan adalah dengan mengkaji seluruh regulasi maupun perundang-undangan yang berkaitan dengan tema investasi maupun OSS yang akan diteliti. Pengumpulan data sekunder dilakukan melalui perolehan sumber data yang dikumpulkan dari berbagai jenis bahan hukum. Pertama, bahan hukum primer memuat peraturan perundang-undangan yang memiliki kekuatan mengikat secara hukum. Kedua, bahan hukum sekunder adalah bahan hukum yang berfungsi untuk menjelaskan bahan hukum primer lebih lanjut seperti arsip penyusunan perundang-undangan yang terkait dengan investasi dan hasil diskusi yang membahas substansi dari bahan primer. Ketiga, bahan hukum tersier atau bahan hukum pendukung (seperti kamus-kamus hukum) dan bahan lain yang digunakan untuk melengkapi data penelitian di luar bidang hukum. ${ }^{17}$ Selanjutnya, dalam mengumpulkan data sekunder teknik yang digunakan adalah melalui penelitian pustaka (library research) serta studi dokumentasi, yaitu mempelajari berbagai jenis penelitian dokumenter yang berkaitan dengan regulasi, buku-buku hukum, artikel penelitian, hasil penelitian terdahulu, dan sebagainya. ${ }^{18}$ Lalu setelah memperoleh data yang diperlukan, data akan diidentifikasi dan diklasifikasi untuk disusun menjadi tulisan hukum dengan mendeskripsikan masalah-masalah yang terdapat didalam penelitian melalui teknik analisis data kualitatif.

${ }^{12}$ Lawi, G.F.K. (2019). Singapura Jadi Negara Favorit Para Pebisnis Dunia, Ini Sebabnya. https://ekonomi.bisnis.com. Diakses pada tanggal 28 Januari 2021.

13 Andriani, R.S. (2019). Goldman Sachs Pangkas Proyeksi Pertumbuhan Empat Negara Macan Asia. https://ekonomi.bisnis.com. Diakses pada tanggal 28 Januari 2021.

${ }^{14}$ Lawi, G.F.K. Op.Cit. Diakses pada tanggal 28 Januari 2021.

15 Zaenuddin, M. (2019). Local Institutional Failures in Decentralized Indonesia: The Case of Batam. In 1st International Conference on Applied Economics and Social Science (ICAESS 2019), 76-80.

${ }^{16}$ Marzuki, P.M. (2005). Penelitian Hukum. Jakarta: Kencana Jakarta. hlm. 93-94.

17 Badan Pembinaan Hukum Nasional. (2015). "Draft Naskah Akademik Peraturan Perundang-Undangan Ruu Tentang Merek", 1-168.

${ }^{18}$ Salim, H.S., \& Nurbani, E.S. (2014). Penerapan Teori Hukum Pada Penelitian Tesis Dan Disertasi.

Jakarta: PT Raja Grafindo Persada. 


\section{HASIL DAN PEMBAHASAN}

\section{Faktor-Faktor yang Mempengaruhi Kemudahan Investasi Asing di Kota Batam, Indonesia beserta Legal Standing OSS dalam Penerapannya}

Berbagai faktor yang mempengaruhi investor untuk menanamkan modalnya terutama di negara-negara berkembang, setidaknya akan memperhatikan ketiga syarat ini. Pertama, syarat ekonomi (economic opportunity) yaitu penanaman modal yang dapat menyediakan keuntungan ekonomis bagi calon investor. Syarat kedua, kestabilan politik (political stability) sangat mempengaruhi pertimbangan investor dalam berinvestasi di suatu negara. Ketiga, kepastian hukum (legal certainty) investor membutuhkan kepastian hukum serta perlindungan dalam berusaha dalam melakukan penanaman modal. ${ }^{19}$

Faktor hukum memiliki peranan andil yang masif dalam dunia penanaman modal. Pemerintah berkewajiban menjamin adanya kepastian hukum serta regulasi yang baik. Tidak hanya hal tersebut, regulasi yang baik juga memerlukan implementasi yang optimal dalam pelaksanaannya. Sayangnya, regulasi Indonesia dipandang tidak efektif dalam kebijakannya dan hal ini menjalar di berbagai dimensi. Pengaturan di sektor perizinan, bea cukai, tenaga kerja, kepemilikan lahan maupun properti, penanaman modal, dan seterusnya. Regulasi yang tidak efektif menimbulkan ketidakpastian hukum dan didalam ketidakpastian hukum investor enggan menanamkan modalnya dan akan melirik ke negara lain yang lebih berkompeten dalam memberikan jaminan kepastian hukum berusaha.

Di Kota Batam sendiri konsistensi penerapan hukum sulit untuk diandalkan. Hal ini diiringi dengan adanya dualisme wewenang antara BP (Badan Pengusaha) Batam dengan Pemkot (Pemerintah Kota) Batam. Pada tahun 2007, Kota Batam ditetapkan sebagai salah satu free trade zone area yang diatur dalam "Undang-Undang Nomor 44 tahun 2007 tentang Kawasan Bebas dan Pelabuhan Bebas". Selang beberapa waktu, Pemerintah kembali menerbitkan "Peraturan Pemerintah Nomor 46 Tahun 2007 tentang Pelabuhan Bebas dan Kawasan Perdagangan Batam". Alasan penetapan Batam sebagai free trade zone (FTZ) antara lain disebabkan oleh adanya krisis yang menunjukkan kondisi perekonomian Indonesia menghadapi stagnasi dalam perkembangannya. ${ }^{20}$

Pertimbangan lain ialah untuk memberikan payung hukum bagi kawasan berikat (Bonded Zone) Batam. Dua tahun setelahnya, pada tanggal 17 November 2009 Kota Batam yang awalnya merupakan area FTZ kemudian berubah menjadi Kawasan Ekonomi Khusus/KEK (special economic zone/SEZ). Ketentuan tersebut kemudian diumumkan dengan pemberlakuan UU No.39 Tahun 2009 yang mengatur mengenai Kawasan Ekonomi Khusus. ${ }^{21}$ Regulasi yang terus berubah-ubah dan tidak konsisten dalam penerapannya akan menimbulkan banyak miskonsepsi diantara para pihak baik petugas hukum, masyarakat yang terkait, maupun investor asing yang kesulitan menyesuaikan perubahan yang tidak pasti.

Regulasi Indonesia dipandang tidak efektif dalam kebijakannya sehingga dapat menimbulkan ketidakpastian hukum bagi para investor terutama dalam bidang perpajakan. Beberapa keluhan yang muncul terkait pajak dikeluhkan oleh pengusaha antara lain mengenai tarif pajak yang terlalu tinggi yaitu sebesar 25 persen untuk penghasilan $\mathrm{Rp}$. 250.000.000 sampai Rp. 500.000.000 per tahun, ${ }^{22}$ jenis pajak yang terlampau banyak, birokrasi yang berbelit-belit menyulitkan wajib pajak dalam melakukan kewajibannya, kedudukan dan kewenangan aparat pajak (fiskus) yang lebih tinggi dibandingkan wajib pajak, kemudian investor yang telah menanamkan modalnya harus dapat menyesuaikan fasilitas perpajakan yang disediakan pemerintah selama perubahan periode FTZ menjadi KEK.

${ }^{19}$ Lubis, R.P., \& Firdaus, M., dan Sasongko, H. (2015). Determinant of Foreign Direct Investment in Indonesia Plantation Sector, Jurnal Bisnis dan Manajemen, 16 (2), 80-89.

${ }^{20}$ Rivani, E. (2016). Op.Cit.

${ }^{21}$ Budiman, D. (2019). Status Free Trade Zone Kota Batam Dalam Persepktif Ekonomi Pertahanan. JEKPEND: Jurnal Ekonomi dan Pendidikan, 2(2), 16-22.

22 Fitriya. (2020). Ulasan Lengkap Pajak Penghasilan: Jenis-Jenis PPh, Objek, Subjek, Tarif dan Contoh. https://klikpajak.id/blog/perhitungan/pajak-penghasilan-jenis-pph-objek-subjek-tarif-perhitungan/. Diakses pada tanggal 18 Februari 2021. 
Abdurrakhman Alhakim et al., Kajian Hukum Perbandingan Kemudahan Investasi Asing di Singapura dan di Kota Batam, Indonesia Beserta Legal Standing OSS Dalam Penerapannya

Tabel 1. Perbandingan Fasilitas Perpajakan pada FTZ dan KEK

\begin{tabular}{|c|c|c|c|}
\hline No. & Jenis Fasilitas & FTZ & KEK \\
\hline \multirow{6}{*}{1.} & Fasilitas PPH Badan & -- & $\cdots$ \\
\hline & a. Investment Allowance & $\mathrm{x}$ & $\sqrt{ }$ \\
\hline & b. Amortisasi dipercepat & $\mathrm{x}$ & $\sqrt{ }$ \\
\hline & c. Pajak Dividen & $\mathrm{x}$ & $\sqrt{ }$ \\
\hline & d. Kompensasi kerugian yang lebih lama & $\mathrm{x}$ & $\sqrt{ }$ \\
\hline & e. Tax Holiday & $\mathrm{x}$ & $\sqrt{ }$ \\
\hline 2. & Fasilitas Pembebasan PPh Pasal 22 Impor & $\sqrt{ }$ & $\sqrt{ }$ \\
\hline \multirow{6}{*}{3.} & Fasilitas PPN dan PPnBM & $\cdots$ & $\cdots$ \\
\hline & a. PPN impor tidak dipungut & $\sqrt{ }$ & $\sqrt{ }$ \\
\hline & b. PPN tidak dipungut atas pembelian dalam negeri & $\sqrt{ }$ & $\sqrt{ }$ \\
\hline & c. Pembebasan PPN dan/atau PPnBM & $\sqrt{ }$ & $\sqrt{ }$ \\
\hline & d. Penyerahan tidak dipungut kepada penerima fasilitas lainnya & $\sqrt{ }$ & $\sqrt{ }$ \\
\hline & e. Pengembalian PPN kepada orang pribadi pemegang paspor luar negeri & $\mathrm{x}$ & $\sqrt{ }$ \\
\hline \multirow{4}{*}{4.} & Fasilitas Bea Masuk dan Cukai & - & $\cdots$ \\
\hline & a. Penangguhan Bea Masuk & $\mathrm{x}$ & $\sqrt{ }$ \\
\hline & b. Pembebasan Bea Masuk & $\sqrt{ }$ & $\sqrt{ }$ \\
\hline & c. Pembebasan Cukai & $\sqrt{ }$ & $\sqrt{ }$ \\
\hline
\end{tabular}

Sistem perpajakan di Indonesia termasuk Kota Batam dilaporkan secara online melalui https://djponline.pajak.go.id/. Dalam sistem elektronik, seluruh rangkaian kewajiban perpajakan sudah terintegrasi dengan biro pajak dan dapat diakses dengan mudah melalui online mulai dari pendaftaran hingga pembayaran pajak. Tujuan penerapan sistem online pajak diantaranya memudahkan wajib pajak dalam melakukan kewajiban perpajakan serta efisiensi waktu dan administrasi. Namun jika dibandingkan dari segi efektifitas, sistem perpajakan saat ini masih harus ada yang dibenahi terutama dalam melaporkan SPT (Surat Pemberitahuan Tahunan). Dalam melakukan kewajibannya, setidaknya wajib pajak harus melalui beberapa tahapan untuk melaporkan pajak kepada negara. Setelah mengisi form laporan tahunan, wajib pajak (badan usaha) diharuskan menyediakan lampiran-lampiran dokumen untuk mendukung informasi yang diberikan. Dokumen keuangan badan usaha yang diperlukan antara lain laporan rugi/laba, balance sheet, rekapitulasi usaha, daftar jumlah penghasilan bruto dan pembayaran PPh Final per masa pajak serta dari masing-masing tempat usaha per bulannya, transkrip kutipan elemen-elemen dari laporan keuangan, dan form 1771 (bagi badan usaha) beserta lampiran-lampirannya masing-masing harus ditandatangani oleh direktur beserta cap legal perusahaan.

Apabila laporan pajak terhitung nihil, maka wajib pajak tetap harus melampirkan berbagai dokumen tersebut dengan lampiran nihil. Jika investor asing yang dikenakan pajak berada di luar kota/negeri, maka dokumen tersebut harus dikirimkan ke luar kota/negeri untuk ditandatangani terlebih dahulu walaupun dokumen tersebut berisi nihil. Setelah semua itu dilakukan, wajib pajak juga harus menunggu kode verifikasi yang dikirimkan melalui email oleh sistem online untuk mengirimkan laporan pajak yang telah dibuat. Hal tersebut sangat bertele-tele dan memakan waktu setidaknya 1 hingga 2 hari untuk melapor pajak. Seharusnya, cukup dengan wajib pajak mencentang keterangan dibawah ini tanpa perlu melampirkan dokumen-dokumen yang terlampau banyak.

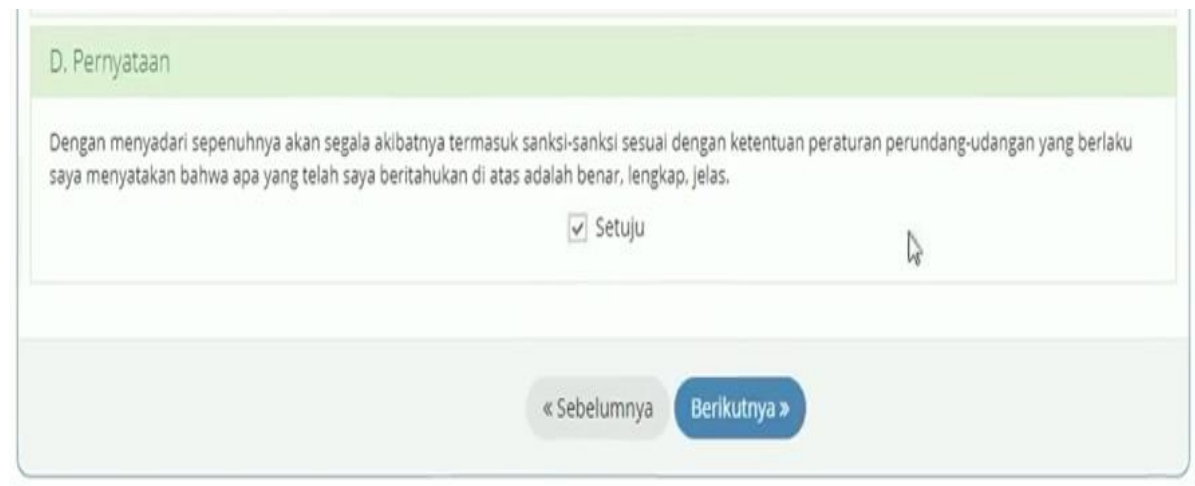

Sumber: https://djponline.pajak.go.id/

Adanya keterangan tersebut, pemerintah dapat mempercayai wajib pajak dan apabila data yang diberikan terbukti tidak sesuai dan melanggar ketentuan dapat dikenakan sanksi yang tegas. Birokrasi yang berbelit-belit dan lampiran dokumen yang terlampau banyak sering menyebabkan server pajak bermasalah terutama jelang penyampaian 
Abdurrakhman Alhakim et al., Kajian Hukum Perbandingan Kemudahan Investasi Asing di Singapura dan di Kota Batam, Indonesia Beserta Legal Standing OSS Dalam Penerapannya

SPT. DJP mengakui bahwa server Ditjen Pajak tidak cukup kuat menampung gelombang data yang terlampau banyak yang masuk sekaligus secara online. Akibatnya, banyak masyarakat mengeluhkan sulitnya mengakses situs bahkan dalam melakukan proses laporan pajak tahunan kepada negara. ${ }^{23}$

Indonesia saat ini menempati peringkat pertama sebagai negara terumit untuk melakukan bisnis dikutip dalam Business Complexity Index Tahun 2020. Ini berarti kemudahan berbisnis di Indonesia paling rumit dibandingkan dengan negara-negara lain. Lembaga riset dan konsultasi TMF Group menerbitkan Global Business Complexity Index Rankings 2020 yang menunjukkan bahwa Indonesia menempati peringkat pertama mengalahkan Cina, Brazil, Yunani, Nikaragua, Argentina, Bolivia, Malaysia, Kolombia serta Ekuador. Berdasarkan indeks tersebut, hal ini terjadi dikarenakan investor asing menganggap undang-undang Indonesia yang ada sudah ketinggalan zaman dan merupakan penghalang yang signifikan dalam menanamkan modal di Indonesia. ${ }^{24}$

Bank Dunia juga menilai hal yang serupa. Negara Indonesia bukanlah tujuan utama bagi penanam modal asing. Investor yang sudah mengenali birokrasi Indonesia akan berusaha menghindar dari negara ini. Permohonan perizinan investasi yang panjang membutuhkan waktu 151 hari dimana untuk memulai suatu usaha diperlukannya 12 prosedur. Sedangkan dana yang harus dikeluarkan investor untuk memulai usaha setidaknya mencapai $131 \%$ dari PDB per kapita. ${ }^{25}$ Peringkat kemudahan berbisnis atau ease of doing business (EoDB) di Indonesia stagnan di posisi 73 dunia sejak dua tahun lalu. Laporan yang dikeluarkan oleh World Bank tersebut umumnya akan menjadi bekal rujukan penanam modal asing untuk berinvestasi di Indonesia. Dalam rangka memperbaiki iklim investasi sekaligus menjawab keluhan para investor pemerintah harus segera melakukan langkah-langkah konkret. ${ }^{26}$

Salah satu upaya dan terobosan baru yang bertujuan untuk meningkatkan daya saing kawasan dan dinamika global serta mendorong pertumbuhan investasi di Indonesia termasuk Kota Batam, pemerintah Indonesia mendirikan sistem OSS (Online Single Submission) untuk mempercepat dan meningkatkan investasi dan usaha melalui penerapan izin usaha terintegrasi secara elektronik. Dalam regulasi terbaru terkait OSS, yakni dalam "Peraturan Pemerintah Nomor 24 Tahun 2018 tentang Pelayanan Perizinan Komersial Terintegrasi Secara Elektronik", pemerintah mengatur jenis, pemohon dan penerbitan izin usaha; pelaksanaan izin usaha; reformasi izin usaha masing-masing departemen. Sistem OSS, kelembagaan OSS, dana OSS; insentif dan disinsentif pelaksanaan izin usaha melalui OSS; penyelesaian masalah dan kendala usaha; dan sanksi. ${ }^{27}$

Sayangnya, implementasi mengenai pelayanan publik OSS dinilai masih belum mencapai harapan untuk mempercepat integrasi dengan Kementerian dan Lembaga terkait. Masa transisi yang lambat terutama pada tingkat daerah yang masih kurang berkoordinasi dengan tingkat pusat yang menimbulkan banyak masalah terkait perizinan investasi. ${ }^{28}$ Salah satu kendala yang ditemukan yakni, waktu diberlakukannya OSS mewajibkan perusahaan untuk menyesuaikan kegiatan usaha dalam anggaran dasarnya dengan KBLI 2017. Belum berjalan lewat 2 tahun, pemerintah kembali meluncurkan KBLI 2020 (Peraturan Badan Pusat Statistik Nomor 2 Tahun 2020) yang mana salah satu pasalnya yaitu pasal 4 menyatakan peraturan KBLI 2017 dicabut dan dinyatakan tidak berlaku.

Meskipun KBLI 2017 sudah dibatalkan oleh KBLI 2020, lembaga Kementrian Hukum \& HAM serta OSS masih mengadopsi KBLI 2017 yang lama dalam sistemnya. Bagaimana cara menjelaskan kepada investor untuk memahami peraturan yang berubah-ubah dan tidak terprediksi. Implikasinya, perusahaan terpaksa berulang kali harus mengeluarkan dana lebih hanya untuk menyesuaikan anggaran dasar perusahaan. Setelah disesuaikan, investor juga terkendala dalam menghadapi sistem OSS yang masih menganut KBLI 2017 sedangkan KBLI 2020 terbaru belum muncul di dalam sistem OSS. Disamping itu, masih banyak lagi polemik yang ditemukan seperti fitur penentuan lokasi usaha yang belum tersambung dengan RTRW (Rencana Tata Ruang Wilayah) serta ketersediaan RDTR

23 Asmara, C. G. (2019). Setiap Tahun Lapor SPT, dan Server Pajak Selalu Bermasalah. https://www.cnbcindonesia.com/news/20190305140100-4-58974/setiap-tahun-lapor-spt-dan-server-pajak-selalu-bermasalah.

Diakses pada tanggal 18 Februari 2021.

${ }^{24}$ Medcom. (2020). RI Jadi Juara 1 Negara Terumit untuk Berbisnis. https://m.medcom.id/amp/8N0jEAAk-ri-jadi-juara-1negara-terumit-untuk-berbisnis. Diakses pada tanggal 16 Februari 2021.

25 Dona, F. (2017). Peran Penanaman Modal Asing (PMA) dalam Pembangunan Ekonomi di Era Otonomi Daerah. AlAhkam Jurnal Ilmu Syari'ah dan Hukum, 2(1).

26 Santoso, Y. I. (2020). Peringkat kemudahan berbisnis Indonesia stagnan di posisi 73, ini kata Kepala BKPM. https://amp.kontan.co.id/news/peringkat-kemudahan-berbisnis-indonesia-stagnan-di-posisi-73-ini-kata-kepala-bkpm. Diakses pada tanggal 16 Februari 2021.

27 Angelica, M., Siraiy, M.S., \& Safei, M. (2019). Permasalahan Kebijakan Pelayanan. https://osf.io. Diakses pada tanggal 26 Januari 2021.

28 Rahayu, I. R. S. (2019). Sistem OSS Masih Banyak Kendala, Terutama Sinkronisasi Daerah dan Pusat. https://www.inews.id/. Diakses pada tanggal 27 Januari 2021. 
Abdurrakhman Alhakim et al., Kajian Hukum Perbandingan Kemudahan Investasi Asing di Singapura dan di Kota Batam, Indonesia Beserta Legal Standing OSS Dalam Penerapannya

(Rencana Detail Tata Ruang), tidak diterimanya email aktivasi, sistem tidak bisa diakses sampai dengan perubahanperubahan versi aplikasi OSS. ${ }^{29}$

Hal ini mungkin dikarenakan ketidaksiapan dalam menangani transformasi nilai yang berdimensi. Faktor lain yang juga ikut turut andil menyulitkan investor antara lain penyelesaian sengketa, penegakan kontrak, perpajakan, pendaftaran properti, dan perdagangan lintas negara. Regulasi tersebut dinilai terlalu banyak, berbelit-belit, sulit diakses, memiliki prosedur yang sangat rumit serta tidak adanya kepastian waktu dan kesatuan pelayanan yang dibutuhkan. ${ }^{30}$ Hal tersebut tentu merugikan kepentingan berbagai pihak bukan hanya masyarakat sendiri tetapi juga bagi pelaku usaha terutama investor asing yang ingin menanamkan modalnya.

Menanamkan modal dengan membangun perusahaan asing investor juga memperhatikan aspek ketenagakerjaan. Seperti yang kita ketahui, ketenagakerjaan dan penanaman modal memiliki hubungan timbal balik yang sangat erat dalam kegiatan usahanya. Di Indonesia, kecenderungan akan peningkatan upah minimum yang tinggi sangat lumrah terjadi. Hampir setiap tahunnya buruh meminta peningkatan upah yang pada realitanya tidak diimbangi dengan kinerja kerja yang berkualitas. Berdasarkan hasil penelitian Federasi Kamar Dagang dan Industri Korea yang membandingkan upah serta lingkungan bisnis di beberapa negara Asia, terlihat bahwa daya saing investasi Indonesia lebih rendah dari China dan Vietnam, dan hanya lebih baik dari Myanmar dan Bangladesh. ${ }^{31}$

Selanjutnya ketidakpastian hubungan kerja diantara perusahaan dan pekerja. Pengusaha Indonesia percaya bahwa "UU Ketenagakerjaan" membebani dunia usaha dan tidak menjadi sarana untuk mempromosikan lingkungan investasi. Hal ini diikuti dengan semakin maraknya aksi demonstrasi para buruh yang bertujuan menuntut kenaikan upah setiap tahunnya. Jika ditelusuri lebih lanjut, para pengusaha dan investor keberatan akan kualitas tenaga kerja Indonesia yang memiliki daya saing rendah dalam hal keterampilan, disiplin dan etika profesi. ${ }^{32}$ Menanggapi hal tersebut, pada tanggal 5 Oktober 2020 lalu Dewan Perwakilan Rakyat Republik Indonesia (DPR RI) bersama Presiden menetapkan Omnibus Law UU Cipta Kerja (Undang-Undang Nomor 11 Tahun 2020 tentang Cipta Kerja) yang diharapkan dapat meningkatkan arus investasi dan memperluas lapangan kerja. Namun hingga saat ini undang-undang tersebut masih menuai banyak kontroversi serta penolakan dari berbagai kalangan. ${ }^{33}$

Menurunnya daya saing di Kota Batam akan menyebabkan akibat yaitu terdapat sebanyak 30 persen dari ratusan perusahaan di Batam yang merencanakan pengalokasian industrinya ke negara lain yang mendukung iklim investasi yang baik dan kondusif untuk berusaha. Tak bisa dipungkiri dari akibat tersebut adalah banyaknya tenaga kerja yang mengalami Pemutusan Hubungan Kerja (PHK). Diperparah pada saat gelombang pandemi melanda, tercatat sekitar 2.000 orang karyawan yang kehilangan pekerjaan. Hal ini akan menambah jumlah pengangguran di Batam yang diiringi dengan pencari kerja di Batam yang selalu meningkat setiap harinya. ${ }^{34}$

\section{Faktor-Faktor yang Mempengaruhi Kemudahan Investasi Asing di Singapura}

Singapura adalah salah satu negara maju di negara kawasan ASEAN yang menduduki urutan pertama dalam laporan bank dunia berjudul "Ease of Doing Business". Sejak Singapura menerapkan kebijakan transparansi dalam kemudahan berinvestasinya, Singapura berhasil menarik ketertarikan para investor asing dalam menanamkan modal di negeri singa ini. Menurut data yang dilaporkan oleh UNCTAD 2016 World Investment Report, Singapura juga sukses meraih urutan ketujuh di antara negara tuan rumah dengan investasi terbanyak di dunia. ${ }^{35}$

Kebijakan resmi investasi asing langsung Singapura mengadopsi pendekatan kebijakan yang diadopsi oleh negara-negara maju. Tidak terdapat pemisahan antara kebijakan dan perlakuan yang membedakan investor asing dengan investor domestik. Hal tersebut menyebabkan tidak adanya diskriminasi antara PMA dan PMDN di Singapura. Fokus pembangunan ekonomi Singapura telah meningkat secara teratur selama beberapa periode. ${ }^{36}$ Sebagai salah satu badan hukum pemerintah Singapura, Economic Development Board telah mengklasifikasikan sejarah pembangunan

29 Mahardhika, L. A. (2019). Implementasi Sistem OSS Masih Hadapi Sejumlah Kendala. https://ekonomi.bisnis.com/read/20190911/9/1147045/implementasi-sistem-oss-masih-hadapi-sejumlah-kendala. Diakses pada tanggal 16 Februari 2021.

${ }^{30}$ Angelica, M., Siraiy, M.S., \& Safei, M. (2019). Op.Cit.

31 Tolok, A. D. (2020). Investor Lebih Pilih Negara ASEAN Lain daripada Indonesia, Kenapa?. https://m.bisnis.com/amp/read/20200628/9/1258764/investor-lebih-pilih-negara-asean-lain-daripada-indonesia-kenapa. Diakses pada tanggal 16 Februari 2021.

32 Kemenperin. (2012). Kenaikan Upah Terlalu Drastis Pemerintah Tidak Probisnis. https://kemenperin.go.id/artikel/5093/ghs. Diakses pada tanggal 16 Februari 2021.

33 Tim Detikcom. (2020). Perjalanan UU Cipta Kerja: Disahkan DPR hingga Diteken Jokowi. https://news.detik.com/berita/d-5239036/perjalanan-uu-cipta-kerja-disahkan-dpr-hingga-diteken-jokowi/2. Diakses pada tanggal 16 Februari 2021.

${ }^{34}$ Rivani, E. (2016). Op.Cit.

${ }^{35}$ Hsu, L. (2012). Inward FDI in Singapore and Its Policy Context, America: Columbia University Press.

${ }^{36}$ Hsu, L. (2012). Ibid 
Abdurrakhman Alhakim et al., Kajian Hukum Perbandingan Kemudahan Investasi Asing di Singapura dan di Kota Batam, Indonesia Beserta Legal Standing OSS Dalam Penerapannya

Singapura dalam beberapa tahap dari 1960-an hingga 2000-an yaitu, 1960-an; 1970-an; 1980-an; 1990-an; dan 2000an di situs resminya. ${ }^{37}$

Perjanjian dan kontrak investasi Singapura didasarkan pada Pasal 37 Singapore Constitution, yang mendorong pemerintah Singapura untuk mengikat kontrak tersebut. Penanaman modal asing yang diklasifikasikan sebagai unsur usaha harus terlebih dahulu terdaftar dalam Business Registration Act (BRA), dengan tetap menerapkan daftar negatif jenis usaha yang dapat diinvestasikan oleh investor asing. Kemudian, Singapura mewajibkan investor untuk mendaftar ulang jenis bisnis yang akan diinvestasikan melalui Accounting and Corporate Regulatory Authority (ACRA). ${ }^{38}$ Investasi asing adalah kunci utama kemampuan Singapura dalam melakukan tingkat pertumbuhan ekonominya. Singapura merupakan negara yang mengajukan prinsip fair and equitable treatment sebagaimana diuraikan dalam Pasal 3 ayat (1) ARC Regional Investment Treaty.

Di Singapura, semua investor asing dapat dengan bebas memiliki kuasa atas $100 \%$ kepemilikan usahanya untuk repatriasi, pengecualian untuk sejumlah area bisnis yang melibatkan keamanan nasional Singapura, seperti telekomunikasi, penyiaran, media, jasa keuangan, hukum, dan bisnis lainnya. ${ }^{39}$ Wilayah usaha milik pemerintah harus dimiliki oleh pemerintah dengan $20 \%$ sahamnya agar dapat terus bekerja sama dalam menjalankan bisnis investasi dengan pemerintah. Pemerintah tidak hanya memberikan pengawasan, tetapi juga memberikan jaminan berupa kepastian hukum di sektor sensitif seperti ketenagakerjaan dan perpajakan. Pemerintah juga memberikan keterbukaan kepada investor asing dalam proses upaya investasi, sehingga investor tetap percaya bahwa Singapura adalah negara tuan rumah yang layak dalam melakukan investasi. ${ }^{40}$

Seluruh perusahaan Singapura wajib membuat laporan keuangan yang sesuai dengan Singapore Financial Reporting Standards (SFRS). Laporan keuangan ini disusun secara transparan agar investor dapat memahami laju perkembangan investasi di Singapura. ${ }^{41}$ Sistem perpajakan di Singapura dilaporkan secara online melalui https://www.iras.gov.sg/. Dengan mengisi form yang diberikan, wajib pajak dapat langsung mengirim laporan tersebut tanpa perlu melampirkan berbagai halaman dokumen. Pelaporan tersebut cukup ringkas dan efektif dan dapat dilakukan dalam kurun waktu 1/2 hingga 1 jam. Kemudian, Singapura juga menerapkan tarif pajak dasar perusahaan yang lebih ringan yaitu sebesar 17\%, tunjangan pajak yang cukup besar bagi usaha kecil dan menengah serta insentif pajak bagi industri tertentu. ${ }^{42}$

Disamping sektor pajak, pemerintah juga memberikan kepastian hukum di sektor ketenagakerjaan. Terdapat kebijakan-kebijakan yang memberikan kepastian hukum dan perlindungan payung hukum bagi para investor (prinsip fair and equitable treatment) dengan tetap memperhatikan perlindungan tenaga kerja hal tersebut membuat investor asing selalu menanamkan modalnya di Singapura. Regulasi tenaga kerja Singapura diatur dalam Undang-Undang Ketenagakerjaan Singapura (Employment Act). ${ }^{43}$ Meskipun upah ditawarkan dengan biaya yang tinggi namun hal tersebut diikuti dengan kemampuan sumber daya manusia yang terampil dan disiplin. Tenaga kerja di Singapura memiliki etos kerja yang baik, bersikap profesional, dan bekerja secara produktif yang sering dibandingkan pula dengan negara Jepang yang terkenal akan etos kerjanya yang disiplin. ${ }^{44}$ Hal-hal tersebut membuat Singapura dianggap dalam jangka panjang akan menjadi negara tuan rumah yang dapat memberikan implikasi positif bagi investor, ditandai dengan adanya jaminan kepastian hukum yang menciptakan iklim investasi kondusif dalam berusaha.

\title{
Perbandingan Faktor-Faktor yang Mempengaruhi Kemudahan Investasi Asing di Kota Batam, Indonesia dan Singapura
}

Berikut tabel rangkuman faktor-faktor yang mempengaruhi kemudahan investasi asing di Kota Batam dan Singapura.

\author{
${ }^{37}$ Hsu, L. (2012). Ibid \\ ${ }^{38}$ Hsu, L. (2012). Ibid \\ ${ }^{39}$ Formal, E., \& Agniezka. (2013). The Foreign Dimension of Singapore's Economic Growth, Bergen: NHH. \\ ${ }^{40}$ Formal, E., \& Agniezka. (2013).
}

${ }^{41}$ Putri, R.R., Chandrawulan, A., \& Amalia, P. (2018). Peringkat Arus Investasi Indonesia Dalam Kerangka Asean-China Free Trade Agreement (Perbandingan Dengan Singapura, Malaysia, Thailand, Dan Vietnam) Ditinjau Dari Prinsip Fair and Equitable Treatment. Jurnal Hukum \& Pembangunan, 48 (2), 275-298.

42 Putri, R.R., Chandrawulan, A., \& Amalia, P. (2018). Ibid.

${ }^{43}$ Lase, I. N. (2018). "Pengaturan Tenaga Kerja Asing Dalam Kegiatan Investasi: Studi Perbandingan Antara Indonesia dan Singapura, USU: Skripsi.

${ }_{44}$ Amna, F. K. (2013). Etos Kerja Dan Budaya Kerja Bangsa Jepang. https://www.scribd.com/doc/171813882/Etos-KerjaDan-Budaya-Kerja-Bangsa-Jepang. Diakses pada tanggal 18 Februari 2021. 
Abdurrakhman Alhakim et al., Kajian Hukum Perbandingan Kemudahan Investasi Asing di Singapura dan di Kota Batam, Indonesia Beserta Legal Standing OSS Dalam Penerapannya

\begin{tabular}{llll} 
No & Faktor & Batam & Singapura \\
\hline 1. UU Penanaman Modal & Kepastian hukum sulit diandalkan. Adanya Adanya jaminan kepastian hukum bagi \\
& & dualisme kewenangan antara Badan investor. Peraturan Penanaman Modal \\
& Pengusahan (BP) Batam serta Pemerintah Kota yang stabil dan tidak berubah-rubah \\
& (Pemkot) Batam. Perubahan peraturan dengan memprioritaskan pembangunan \\
& penanaman modal FTZ (free trade zone) & ekonomi Singapura dalam beberapa tahap \\
& & menjadi KEK (Kawasan Ekonomi Khusus). & dari 1960an hingga tahun 2000an.
\end{tabular}

2. Sistem Perpajakan

Sistem perpajakan dilaporkan secara online melalui https://djponline.pajak.go.id/. Dalam melakukan kewajibannya, setidaknya wajib pajak harus melampirkan berbagai jenis dokumen serta menunggu kode verifikasi sehingga memakan waktu setidaknya 1 hingga 2 hari untuk melapor pajak. Birokrasi yang berbelit-belit dan lampiran dokumen yang terlampau banyak sering menyebabkan server pajak bermasalah terutama jelang penyampaian SPT. Para pengusaha juga mengeluhkan mengenai tarif pajak yang terlalu tinggi yaitu sebesar 25 persen, jenis pajak yang terlampau banyak, birokrasi yang berbelit-belit, serta posisi dan kewenangan petugas pajak yang terlampau tinggi dibandingkan wajib pajak.

3. Sistem Perizinan Pemerintah Indonesia menciptakan sistem OSS (Online Single Submission) untuk mempercepat dan meningkatkan investasi dan usaha melalui penerapan izin usaha terintegrasi secara elektronik. Dalam regulasi terbaru terkait OSS, yakni dalam Peraturan Pemerintah Nomor 24 Tahun 2018 tentang Pelayanan Perizinan Komersial Terintegrasi Secara Elektronik

Sistem perpajakan di Singapura dilaporkan secara online melalui https://www.iras.gov.sg/. Dengan mengisi form yang diberikan, wajib pajak dapat langsung mengirim laporan tersebut tanpa perlu melampirkan berbagai halaman dokumen. Pelaporan tersebut cukup ringkas dan efektif dan dapat dilakukan dalam kurun waktu 1/2 hingga 1 jam. Kemudian, Singapura juga menerapkan tarif pajak dasar perusahaan yang lebih ringan yaitu sebesar $17 \%$, tunjangan pajak yang cukup besar bagi usaha kecil dan menengah serta insentif pajak bagi industri tertentu.

Perjanjian investasi Singapura didasarkan pada Pasal 37 Singapore Constitution. Penanaman modal asing yang diklasifikasikan sebagai unsur usaha harus terlebih dahulu terdaftar dalam Business Registration Act (BRA) lalu mewajibkan investor untuk mendaftar ulang jenis bisnis yang akan diinvestasikan melalui Accounting and Corporate Regulatory Authority (ACRA).

4. Sistem Ketenagakerjaan

Undang-undang Ketenagakerjaan dinilai memberatkan dunia usaha dalam menggalakkan iklim investasi. Hampir setiap tahunnya terjadi aksi demonstrasi buruh meminta peningkatan upah yang pada realitanya tidak diimbangi dengan kinerja kerja yang berkualitas. UU cipta kerja telah disahkan namun hingga saat ini masih memperoleh penolakan dari sejumlah kalangan.

Undang-Undang Ketenagakerjaan Singapura (Employment Act) yang memberikan kepastian hukum bagi para investor (prinsip fair and equitable treatment) dengan tetap melindungi kepentingan tenaga kerja. Meskipun upah ditawarkan dengan biaya yang tinggi namun hal tersebut diikuti dengan kemampuan sumber daya manusia yang terampil.

\section{SIMPULAN}

Berdasarkan penelitian yang dilakukan, kemudahan investasi diteliti dari berbagai faktor yaitu di bidang kepastian hukum, perpajakan, ketenagakerjaan, dan perizinan sistem OSS Indonesia termasuk Kota Batam masih belum sepenuhnya mendukung iklim investasi yang kondusif dalam berusaha dibandingkan dengan negara Singapura. Berikut beberapa hal yang dapat dipelajari dari perbandingan kemudahan investasi asing di Kota Batam dan Singapura.

1. Menjalankan dengan benar UU Penanaman Modal, yaitu konsisten dalam penerapan peraturan yang telah ditetapkan agar terciptanya kepastian hukum bagi investor asing.

2. Mereformasi sistem perpajakan menjadi lebih ringkas dan efisien tanpa perlu melampirkan banyak jenis dokumen agar server pajak dapat menampung data dengan baik, menghilangkan proses kode verifikasi, serta menyetarakan kedudukan wajib pajak dan petugas pajak secara adil.

3. Menyederhanakan sistem perizinan yaitu OSS yang dapat dikatakan sebagai peningkatan yang cukup signifikan, namun masih memerlukan koordinasi yang terpadu antara pemerintah pusat dan daerah.

4. Memperbaiki sistem ketenagakerjaan dengan tetap memperhatikan upah minimum yang layak dan diiringi dengan peningkatan kualitas tenaga kerja atau sumber daya manusia Indonesia yang berkompeten. Jika hal tersebut benar-benar dilakukan oleh berbagai pihak terkait baik oleh masyarakat, pemerintah daerah, dan 
Abdurrakhman Alhakim et al., Kajian Hukum Perbandingan Kemudahan Investasi Asing di Singapura dan di Kota Batam, Indonesia Beserta Legal Standing OSS Dalam Penerapannya

pemerintah pusat yang saling bekerjasama dan bersinergi dalam meningkatkan daya saing di bidang penanaman modal, niscaya investor asing akan melirik Kota Batam sebagai ladang investasi yang memiliki potensi sebanding dengan Singapura untuk menanamkan modalnya.

\section{DAFTAR PUSTAKA \\ Buku}

Asmara, C. G. (2019). Setiap Tahun Lapor SPT, dan Server Pajak Selalu Bermasalah

Badan Pembinaan Hukum Nasional. (2015). "Draft Naskah Akademik Peraturan Perundang-Undangan Ruu Tentang Merek

Formal, E., \& Agniezka. (2013). The Foreign Dimension of Singapore's Economic Growth, Bergen: NHH

Hsu, L. (2012). Inward FDI in Singapore and Its Policy Context, America: Columbia University Press

Marzuki, P.M. (2005). Penelitian Hukum. Jakarta: Kencana Jakarta

Salim, H.S., \& Nurbani, E.S. (2014). Penerapan Teori Hukum Pada Penelitian Tesis Dan Disertasi. Jakarta: PT Raja Grafindo Persada

\section{Peraturan Perundang-Undangan}

Undang-Undang Nomor 44 tahun 2007 tentang Kawasan Bebas dan Pelabuhan Bebas

Undang-Undang Nomor 11 Tahun 2020 tentang Cipta Kerja

\section{Skripsi}

Lase, I. N. (2018). "Pengaturan Tenaga Kerja Asing Dalam Kegiatan Investasi : Studi Perbandingan Antara Indonesia dan Singapura, USU: Skripsi

\section{Jurnal}

Arliman, L. (2018). Peran Investasi dalam Kebijakan Pembangunan Ekonomi Bidang Pariwisata di Provinsi Sumatera Barat. Kanun Jurnal Ilmu Hukum, 20(2), 273-294

Budiman, D. (2019). Status Free Trade Zone Kota Batam Dalam Persepktif Ekonomi Pertahanan. JEKPEND: Jurnal Ekonomi dan Pendidikan, 2(2), 16-22

Dona, F. (2017). Peran Penanaman Modal Asing (PMA) dalam Pembangunan Ekonomi di Era Otonomi Daerah. AlAhkam Jurnal Ilmu Syari'ah dan Hukum, 2(1)

Julianti, L., \& Subekti, R. P. (2018). Standar Perlindungan Hukum Kegiatan Investasi Pada Bisnis Jasa Pariwisata Di Indonesia. Kertha Wicaksana, 12(2), 156-166

Kartikasari, D. (2017). The Effect of Export, Import and Investment to Economic Growth of Riau Island Indonesia. International Journal of Economics and Financial Issues, 7(4), 663-667

Lubis, R.P., \& Firdaus, M., dan Sasongko, H. (2015). Determinant of Foreign Direct Investment in Indonesia Plantation Sector, Jurnal Bisnis dan Manajemen, 16 (2), 80-89

Ningsih, D., \& Sari, S. I. (2018). Pengaruh Investasi dan Tenaga Kerja Terhadap Pertumbuhan Ekonomi di Kota Batam. Jurnal Akuntansi Barelang, 3(1), 21-31

Putri, R.R., Chandrawulan, A., \& Amalia, P. (2018). Peringkat Arus Investasi Indonesia Dalam Kerangka AseanChina Free Trade Agreement (Perbandingan Dengan Singapura, Malaysia, Thailand, Dan Vietnam) Ditinjau Dari Prinsip Fair and Equitable Treatment. Jurnal Hukum \& Pembangunan, 48 (2), 275-298

Rivani, E. (2016). Transformasi Batam menjadi KEK untuk memperbaiki iklim investasi. Info Singkat Ekonomi Dan Kebijakan Publik, VIII, 6

Sari, M., Syechalad, M. N., \& Majid, S. A. (2016). Pengaruh investasi, tenaga kerja dan pengeluaran pemerintah terhadap pertumbuhan ekonomi di Indonesia. Jurnal Ekonomi Dan Kebijakan Publik Indonesia, 3(2), 109-115

Zaenuddin, M. (2019). Local Institutional Failures in Decentralized Indonesia: The Case of Batam. In 1st International Conference on Applied Economics and Social Science (ICAESS 2019), 76-80

\section{Website}

https://amp.kontan.co.id/news/peringkat-kemudahan-berbisnis-indonesia-stagnan-di-posisi-73-ini-kata-kepala-bkpm https://batam.tribunnews.com/

https://bplawyers.co.id/

https://ekonomi.bisnis.com

https://ekonomi.bisnis.com/read/20190911/9/1147045/implementasi-sistem-oss-masih-hadapi-sejumlah-kendala

https://iteba.ac.id/

https://kemenperin.go.id/artikel/5093/ghs

https://klikpajak.id/blog/perhitungan/pajak-penghasilan-jenis-pph-objek-subjek-tarif-perhitungan/ 
Abdurrakhman Alhakim et al., Kajian Hukum Perbandingan Kemudahan Investasi Asing di Singapura dan di Kota Batam, Indonesia Beserta Legal Standing OSS Dalam Penerapannya

https://m.bisnis.com/amp/read/20200628/9/1258764/investor-lebih-pilih-negara-asean-lain-daripada-indonesia-kenapa https://m.medcom.id/amp/8N0jEAAk-ri-jadi-juara-1-negara-terumit-untuk-berbisnis

https://news.detik.com/berita/d-5239036/perjalanan-uu-cipta-kerja-disahkan-dpr-hingga-diteken-jokowi/2

https://osf.io

https://www.cnbcindonesia.com/news/20190305140100-4-58974/setiap-tahun-lapor-spt-dan-server-pajak-selalubermasalah

https://www.inews.id/

https://www.pengadaanbarang.co.id/

https://www.scribd.com/doc/171813882/Etos-Kerja-Dan-Budaya-Kerja-Bangsa-Jepang 